\title{
Design and Fabrication of Soya Milk Extracting Machine
}

\author{
Faluyi Olufemi, Opadoja Dele, Adedoyin, R.A \\ Dept. of Mechanical Engineering \\ Osun State Polytechnic, Iree, Nigeria.
}

\begin{abstract}
1.0 Abstract:- Soya milk is aqueous liquid obtained from extraction of milk from soya bean. It involves grinding of soaked soya beans with water to produce slurry, mixed of the slurry with water in order to separate the milk from chaff and sieving of the milk from the paste. Soya milk extractor was designed and fabricated with locally source materials which are stainless steel, hopper, bearing, spring, shaft, frame, pulley, belt, electric motor, filtering chamber, net, blending unit, mild steel, angle iron. These help in reducing the cost of the production. This machine included the filtering net and the water chamber to ease the workload of the operator handling the machine. It can grind $8.301 \mathrm{~g} / \mathrm{s}$ and produce 33.12 liters in an hour. It reduces the cost and enhances the production of the soya milk.
\end{abstract}

Keywords: Filtering net, Soya milk, Water Chamber

\subsection{INTRODUCTION}

Soya milk is aqueous liquid obtained from extraction of milk from soya bean. It involves grinding of soaked soya beans with water to produce slurry, mixed of the slurry with water in order to separate the milk from chaff and sieving of the milk from the paste (Gbabo et al.,2012).

The consumer's enlightenment on health effects of dairy milk consumption has contributed in acceptability andpopularity of soya milk (Gbabo et al., 2012; Jinapong et al., 2008). Dairy milk consumption was reported by McGee (2004) to increase the risk of suffering from certain health problems such as cow milk allergy, which is not found in grains drink. According to Amusa et al.(2005) soya milk has numerous benefits such as social, economic, nutritional and medicinal for its numerous consumers. The affordability of this milk compared to other none alcoholic beverages such as soft drinks have also contributed in making it popular among the people. The major problems associate with locally processed soya milk is its contamination and short shelf life, also the production process is tedious and time consumption (Odu et al., 2012). The contamination of the milk could be as result of rusting of the processing equipment which is mostly made from mild steel material. Also the process involve different stages using different equipment which makes the production process tiresome, time consuming and the products are predisposed to contamination. In additional, there is possibility of contamination of beverages as result of wearing of component parts of milling plate with time of use (Gana, 2011).

According to FAO (2001) and Olaoye (2011), soyabeans is considered as one very important grain grown commercially in more than 35 countries of the world. (Anuonye, J, 2006) concluded that soyabean contains $40 \%$ protein, 35\% total carbohydrate and $20 \%$ cholesterol-free oil. Smith and Circle (1972) opined that mineral content of whole soyabean is about $1.7 \%$ of potassium, $0.3 \%$ of Magnesium, $110 \mathrm{ppm}$ iron, $50 \mathrm{ppm}$ zinc and $20 \mathrm{ppm}$ copper. Soyabean is the world leading vegetable oil and accounts for about $20 \%$ to $24 \%$ of all fats and oil in the world(Adebayo, et al., 2009). Soyabean is becoming increasingly important in agriculture because it is a food source in human and animal nutrition. Soyabean is among the major industrial and food crops grown in every continent. The crop can be successfully grown in many states in Nigeria using low agricultural input. Soyabean cultivation in Nigeria has expanded as a result of its nutritive and economic importance and diverse domestic usage(Adeleke, et al.,2000) It is also a prime source of vegetable oil in the international market. Soyabean has an average protein content of $40 \%$ and is more protein-rich than any of the common vegetable or animal food sources found in Nigeria. Soyabean seeds also contain about $20 \%$ of oil on a dry matter basis, and this is $85 \%$ unsaturated and cholesterol-free(Aworanti et al., 2013).

It is good for food-soya-milk, soya-cheese, dadawa, Tom Brown (infant weaning food); it is the source of an excellent vegetable oil, is used in industry, improves soil fertility and controls the parasitic weed, stock feed, especially for poultry, the haulms provide good feed for sheep and goats(Sudajan, et al., 2003). The aim is to fabricate a workable soya milk extracting machine which will include filter in other to reduce the stress that the operators are passing through during the sieving section and also the chamber where the water will be flowing without any external effort by operators will be attached to it. It is unhygienic when the soyamilk is being grinded and the operator will be using hands to sieve it and at the same time he will be using ordinary hands to be pouring water into the hopper. This machine will solve this unhygienic problem.

\subsection{MATERIALS AND COMPONENTS}

The soyabeans extractor was constructed using stainless steel materials and it is made of the following components, Hopper, bearing, spring, shaft, frame, pulley belt, filtering chamber, net, Blending unit, mild steel, angle iron. 


\subsubsection{MACHINE DESCRIPTION}

i) Blending unit: This unit was made up of the following sub-component parts: outer casing, hopper, delivery tube, blending chamber, blending blade, shaft, pulley, V-belt and $2 \mathrm{hp}$ electric motor.

ii) Pasteurization unit: This unit is made up of the following sub-component parts: stirrer, inner casing, water jacket, milk inlet and outlet valves, water inlet and draining valves, external casing.

\subsubsection{DESIGN ANALYSIS OF MACHINE COMPONENTS}

Determination of power requirement, The machine power requirement is a function of force up on materials inside the blending chamber such as weight of the blending blade, the shaft, and machine pulley.

It is given by below Equations (1)-(5) as reported by Khurmi and Gupta (2005).

$\mathrm{P}=\frac{2 x \pi x N X \tau}{60}$

$\tau=F \times r_{d}$

$F=M \times r_{d} \times \omega^{2}$

$\omega=\frac{2 X \pi N}{60}$

$M=\left(M s y+M_{B}+M s+M p+M_{W T}\right)$

where, $P=$ power required by the machine $(\mathrm{W}) ; F=$ the total force $(\mathrm{N}) ; \tau=$ the torque generated $(\mathrm{N} \mathrm{m})$,

the $M=$ total mass of the material contain in the blending chamber $(\mathrm{kg})$;

$\omega=$ angular angular speed of the blending blade (rpm);

$M_{S Y}=$ mass of grain $(\mathrm{kg})$;

$M_{B}=$ mass of blending blade $(\mathrm{kg})$;

$M_{S}=$ mass of the shaft $(\mathrm{kg})$;

$M P=$ mass of the pulley $(\mathrm{kg}) ; M_{W T}=$ mass of the water $(\mathrm{kg})$;

$\pi=$ constant;

$r d=$ radius of the blade $(\mathrm{m})$;

$N=$ revolution per minute $(\mathrm{rpm})$.

\subsubsection{MASS OF SOYA BEANS TO BE PROCESSED AT A TIME}

The mass of soya beans to be processed is fundamental in computation of power needed by the

machine. Considering the machine volumetric capacity to be $0.3632 \mathrm{~m} 3$ (144 kg) per day and a batch is expected to be complete in 5 minutes, then the mass of material processed per batch was determined using Equation (6) reported by Gbabo (2005).

$\mathrm{M}_{\mathrm{b}}=\rho g\left(\frac{V d x T b}{T T}\right)$

where, $M b=$ mass of material to be processed at a time $(\mathrm{kg})$;

$\rho g=$ bulk density of the grains $(\mathrm{kg} \mathrm{m}-3)$;

$V d=$ volume of material to be processed per day (m3);

$T T=$ total time required to process the material (minutes),

$T b=$ expected time to process the materials at a time (minutes).

Determination of mass of blending blades

The mass of the blending blades is vital in computation of the power requirement of the machine and it was computed using the following Equations (7) and (8) reported by Gbabo (2005).

$M_{B}=\rho_{B} \times V_{B}(7)$

$M_{B}=\rho_{B} \times\left(N_{B}\left(L_{B} \times B_{B} \times T_{B}\right)+\pi h_{B}\left(r^{2 H B E}-r^{2} H B I\right)\right.$

where, $M B=$ the mass of the blending blade $(\mathrm{kg})$;

$V B=$ the volume of blending blade (m3); 
$\rho B=$ the density of blade

(stainless steel) (kg m-3);

$N B=$ the number of horizontal blades $(\mathrm{m})$;

$L B=$ the length of horizontal blade (m);

$B B=$ the breadth of horizontal blade $(\mathrm{m})$;

$T B=$ the thickness of horizontal blade $(\mathrm{m})$;

$h h B=$ the height of blade housing $(\mathrm{m})$;

$r H B E=$ the total radius of blade housing $(\mathrm{m})$;

$r H B I=$ the internal radius of blade housing $(\mathrm{m})$;

$\pi=$ constant $=$ Mass of the central shaft

The mass of the central shaft is important in computation of power needed by the machine and was determined from the relationship reported by Gbabo (2005)

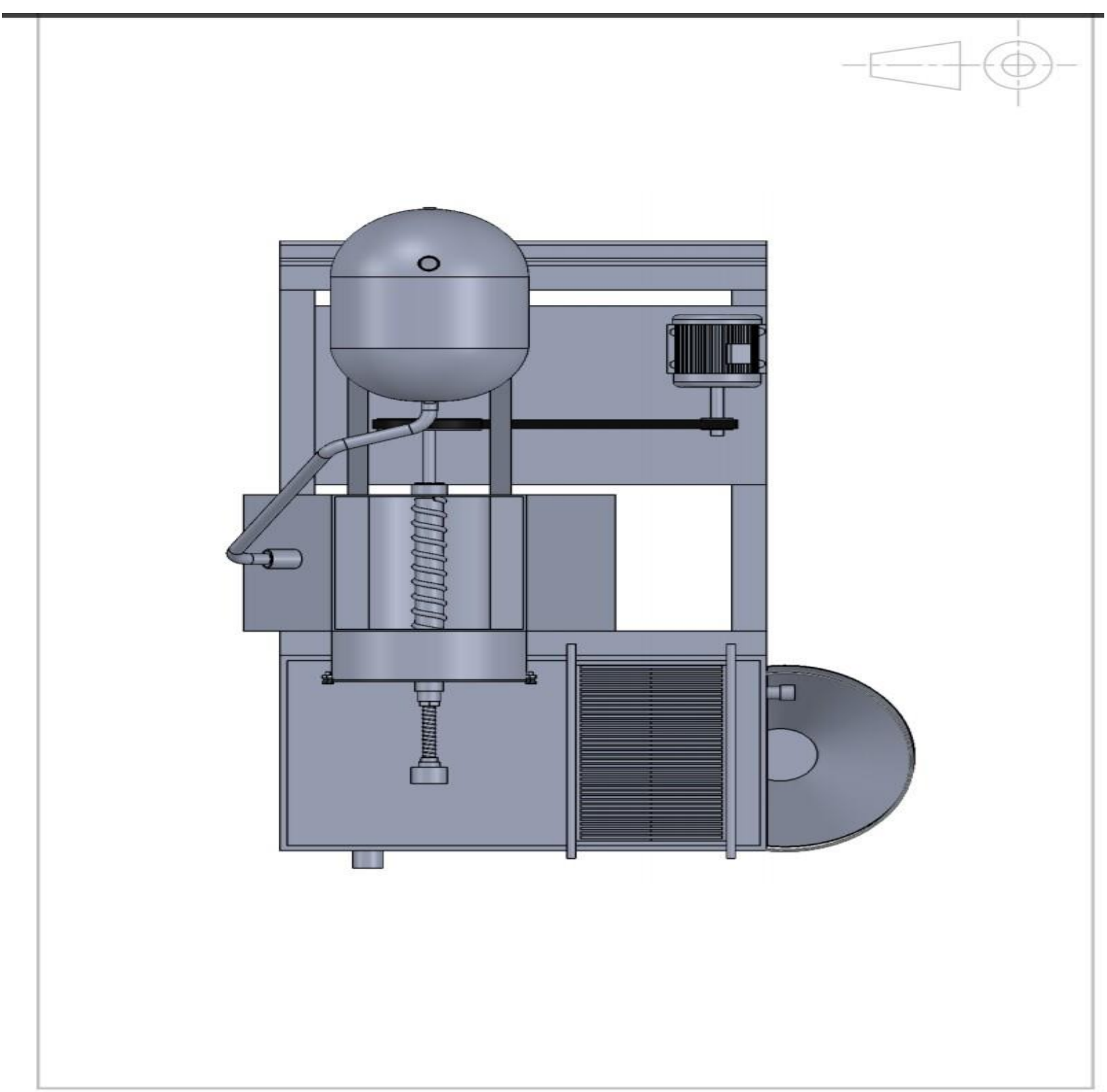




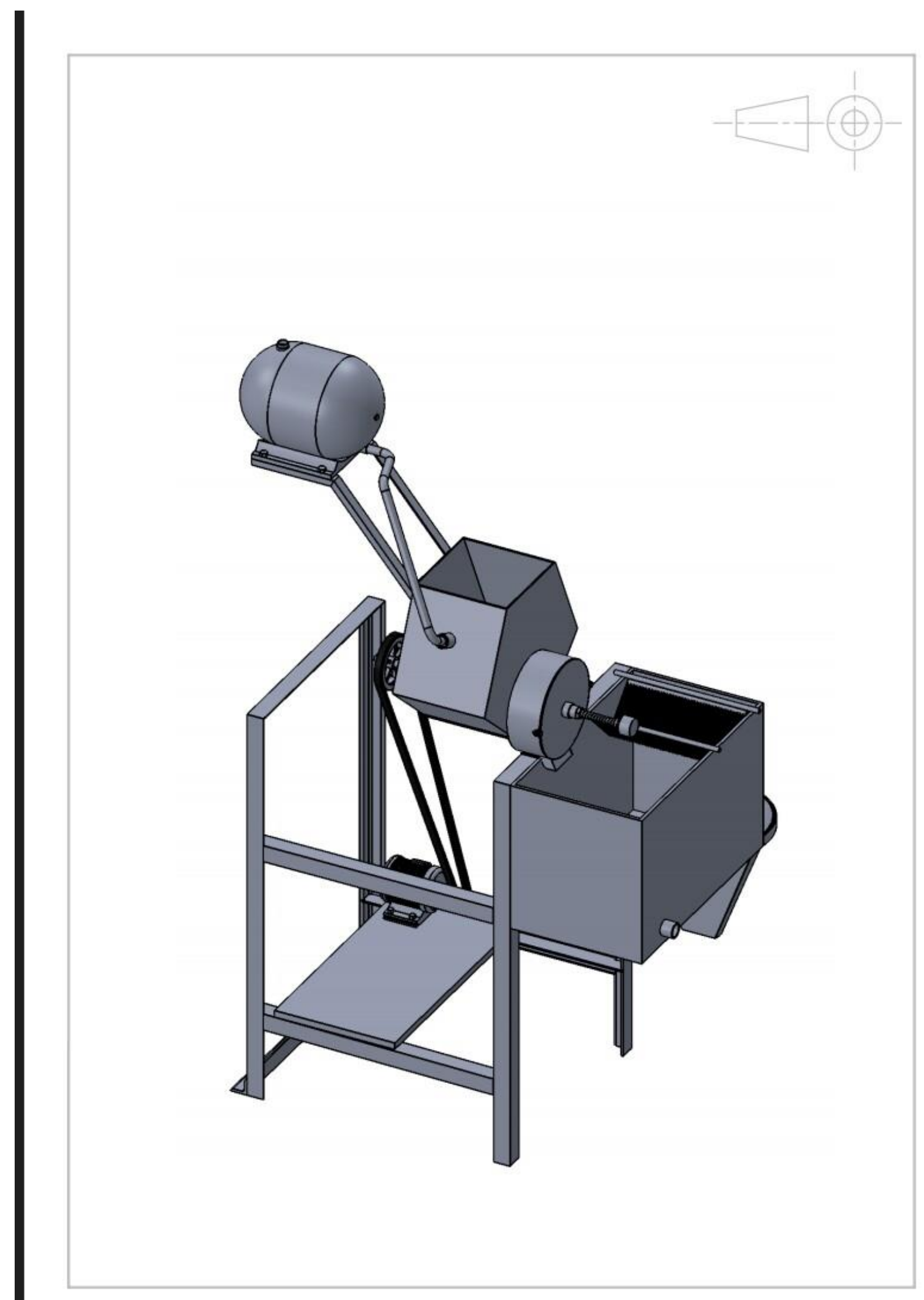




\subsection{RESULTS AND DISCUSION}

The performance of the machine was achieved by carrying out test on individual unit in the machine.

\subsubsection{TESTING OF THE PERFORMANCE OF THE MACHINE}

To test the milling machine a basket of soya beans was boiled and dehulled, its weight was obtained and ground in the machine and the time taken to get a satisfactory grinding was recorded. Table 1 shows the results obtained for the grinding operation. The grounded soya beans was allowed to pass through all the stages i.e. grinding, filtering, boiling and the total time it took to get the final milk was also recorded as shown in table 2

TABLE1: GRINDING RATE ANALYSIS

\begin{tabular}{|l|l|l|}
\hline S/N & WEIGHT OF SOYAMILK(g) & TIME TAKEN TO GRIND(s) \\
\hline 1 & 1024 & 126 \\
\hline 2 & 1062 & 129 \\
\hline 3 & 1052 & 123 \\
\hline TOTAL & 3138 & 378 \\
\hline
\end{tabular}

TABLE 2 OVERALL RATE OF PRODUCTION ANALYSIS

\begin{tabular}{|l|l|l|l|}
\hline S/N & MASS OF SOYA BEANS(g) & VOLUME PRODUCED(L) & TIME TAKEN(s) \\
\hline 1 & 1024 & 17 & 1920 \\
\hline 2 & 1062 & 17 & 1860 \\
\hline 3 & 1052 & 17 & 1740 \\
\hline TOTAL & 3138 & 51 & 5520 \\
\hline
\end{tabular}

\subsubsection{DISCUSSION}

For table 1, Grind rate of the machine can be obtained by:

$\mathrm{Gr}=\frac{\text { TOTALWEIGHTOFSOYABEANS }(\mathrm{g})}{\operatorname{TOTALTIMETAKEN}(\mathrm{s})}=\frac{3138}{378}=8.301 \mathrm{~g} / \mathrm{s}$

For table 2, the overall rate of production analysis

This table shows that the machine produce $51 \mathrm{~L}$ of soyabeans in 5520 seconds

And also for one second i.e

$1 \mathrm{~s}=\frac{51}{5520}=0.0092$ litres $/ \mathrm{s}$

This means that this machine can grind $8.301 \mathrm{~g} / \mathrm{s}$ in second and produce 0.0092 litres per second and it also imply that this machine can produce 33.12 litres per hour, this shows that the production rate of this machine is high which will help to produce large amount of production in a short time if maintain.

\subsubsection{MODE OF OPERATIONS OF THE MACHINE}

The blending blade was fixed on the vertical shaft inside the blending chamber. The water tank was mounted on the machine. The tank was filled with water to the required level. The grains was fed into the machine through the hopper. The power source was then switched on for blending operation. Water tank was opened for flow of water into the machine for washing of the milk. The milk outlet valve was opened for out flow of extracted milk to the pasteurization chamber. The temperature of the water was monitored through the temperature gauge. The pasteurizer outlet valve was open for outflow of the milk. The water jacket outlet valve was opened for draining of the used water.

\subsubsection{CONCLUSION}

The results shows that the machine is capable of grinding $8.301 \mathrm{~g} / \mathrm{s}$ in second and produce 0.0092 liters which imply that it can produce 33.12 liters per hour. It means that this machine will reduce drastically the stress that people pass through in producing soya beans. It has water storage, and net which means that they don't need to be using hands to pour water into the hopper and also they don't need to use hands to sieve soyamilk again because of the net that have been attached to it. This machine reduce the stress of sieving, pouring of water and at the same time increase the production rate.

\subsubsection{RECOMMENDATION}

Stainless steel plate is recommended incase of producing for sale because this machine is a prototype which we use mild steel for. Also, there is room for improvement in the efficiency and physical outlook of the machine. We also recommend that this write up in design and fabrication of this project should serve as a stepping stone for further and well defined fabrication. 


\section{REFERENCE}

[1] Adekanye, T.A., and J.O. Olaoye. 2013. Performance evaluation of motorized and treadle cowpea threshers. Agricultural Engineering International: the CIGR Journal, 15(4): 300-306.

[2] Adebayo-Tayo, B. C., A. A. Adegoke, and O. J. Akinjogunla. 2009. Microbial and physicochemicalquality of powdered soymilk samples in Akwalbom, South Southern Nigeria. African Journal of Biotechnology, 8(13): 3066-3071

[3] Adeleke, O. E., B. A. Adeniyiand A. A. Akinrinmisi. 2000. Microbiological quality of local soymilk: a public health appraisal. African Journal Biomedical Research, 3(2): 89-92.

[4] Amusa, N. A., O. A. Ashaye, A. A.Aiyegbayo, M. O. Oladapo, M. O. Oni, and O. O. Ajolabi. 2005. Microbiological and nutritional quality of hawked sorrel drinks (soborodo) (the Nigerian locally brewed soft drinks) widely consumed and notable drinks in Nigeria. Journal of Food Agricultureand Environment, 3(3-4): 47-50.

[5] Ajav, E.A., and B.A.Adejumo. 2005. Performance evaluation of an okra thresher. Agricultural Engineering International: the CIGR E-journal, Manuscript PM 04006 Vol. VII.

[6] Allen, C.A.W., and K.C.Watts.1998.Design of a belt thresher for cowpea beans.Agricultural Mechanization in Asia, Africa and Latin America, 29(3): 42-46.

[7] Amadu, N.2012. Development and performance evaluation of an improved soybean thresher.Unpulished M. Sci thesis.

[8] Anuonye, J. C. 2006. Effect of extrusion process variables on physioco-chemical, sensory, microbial and storage properties of products from acha (Digitariaexilis) and soybean (Glycine max (L) Merill) flour blends.Ph.D.Department of Food Science and Technology University of Agriculture, Makurdi Nigeria.

[9] Aworanti, O. A., S. E. Agarry, and A. O. Ajani. 2013. Statistical optimization of process variables for biodiesel production from waste cooking oil using heterogeneous base catalyst. British Biotechnology Journal, 3(2): 116-132.

[10] Brooks, A. A., N. U. Asamudo,and F. C. Udoukpo. 2003. Microbiological and physico-chemi cal analysis of soymilk and soyflour sold in Uyometropolis,Nigeria.Global Journal Pure and Applied Sciences, 9(4): 457-464.

[11] Gana, I. M. 2011. Development and performance evaluation of grain drinks processing machine. M.S. thesis.Minna, Nigeria:Federal University of Technology.

[12] Gbabo, A. 2005. Development and testing of rotary dryer for the indigenous cottage sugar industry in Nigeria.Sugar Tech, 7(2-3): 57-66.

[13] Gbabo A., I. M. Gana and A. I. Peter. 2016. Interactive study of some mechanical parameters of an automated grain drinks processing machine with respect to its blending efficiency. International Journal of Engineering Research and Technology, 5(10): 514-518.

[14] Gbabo, A., I. M. Gana, and S. M. Dauda. 2012. Effect of blade types on the blending efficiency and milk consistency of a grains drink processing machine. Academic Research International, 2(3): 41-49.

[15] Gbabo, A., and J. C. Igbeka. 2003. Development and performance of a sugar centrifuge. Sugar Tech, 5(3): 131-136. Gesinde, A. F., O. M. Oyawoye, and A. Adebisi. 2008. Comparative studies on the quality and quantity of soymilkfrom different varieties of soybean.Pakistan Journal of Nutrition, 7(1): $157-160$.

[16] Ikpeme-Emmanuel, C. A., J. Okoi, and N. C. Osuchukwu. 2009. Functional, anti nutritional and sensory acceptability of taro and soybean based weaning food.African Journal of Food Science, 3(11): 372-377.

[17] Jinapong, N., M. Suphantharika, and P. Jamnong. 2008. Production of instant soymilk powders by ultrafiltration, spray drying and fluidized bed agglomeration. Journal of Food Engineering, 84(2): 194-205.

[18] Nwaigwe, K. N., C. Nzediegwu, and P. E. Ugwuoke. 2012. Design, construction and performance evaluation of a modified cassava milling machine. Research Journal of Applied Science Engineering and Technology, 4(18): 3354-3362.

[19] Nwobosi, P. N. U., N. R. Isu, and O. O. Agarry. 2013. Influence of pasteurization and use of natural tropical preservatives on the quality attributes of tiger nut drink during storage. International Journal of Food and Nutrition Science, 2(1): $27-31$.

[20] Odu, N. N., N. N. Egbon, and I.O. Okonko. 2012. Assessment of the effects of different preservatives on the shelf-life of soymilk stored at different temperature. Researcher, 4(6): 62-69.

[21] NSRL. 2010. National soybean research laboratory. Soybean Processing.Threshing and Transport. Available at: www.nsrl.illinois.edu. (Accessed $12 / 10 / 2015)$

[22] Olaoye, J. O. 2011. Development of a treadle operated abrasive-cylinder for threshing cowpea. International Journal of Engineering Science and Technology, 3(12): 8548- 8557.

[23] Sessiz, A.1998. Studies on design of spike-tooth and rasp-bar type axial flow type threshing units and on development of their appropriate prototypes. Ph.D. Thesis. Trakya University, Graduta School of National and Applied Sciences.Agricultural Machinery Main science Section. Edirne, Turkey.

[24] Sharma, K. D., and R.S. Devnani.1980.Threshing studies on soybean and cowpea. Agricultural Mechanization in Asia, Africa and Latin America (AMA), 33(2):65-68.

[25] Smith, A. K. and S. J. Circle.1972.Chemical composition of the seed. In soybeans: chemistry and technology, AVI publication Co., Smith A. K, Circle S. J (eds), Westport,Connecticut, 1: 6192

[26] Sudajan, S., V. M. Salokhe, S. Chusilp, and V. Plermkamon. 2003. Power requirement and performance factors of a sunflower thresher. Agricultural Science Journal, 4: 4-6 (Suppl.): 205208.

[27] Spokas, L., D. Steponavicius, and S. Petkevicius.2008. Impact of technology parameters of threshing apparatus on grain damage. Agronomy Research, 6(9): 67-376.

[28] Vejasit, A., and V. M. Salokhe. 2004. Studies on machine-crop parameters of an axial flow thresher for threshing soybean. Agricultural Engineering International: the CIGR Journal, (6): 1-12. Manuscript No. 04004. 